\title{
Efek Formula Daun Bayam dan Rumput Laut Meningkatkan Kandungan Kalsium dalam Produk Nori yang Disukai
}

\section{Effect of Spinach Leaf and Seaweed Formula Increase Calcium Content in Preferred Nori Products}

\author{
Reni Indriyani ${ }^{1}{ }^{凶}$, Dewi Sri Sumardilah ${ }^{1}$ \\ ${ }^{1}$ Jurusan Gizi, Politeknik Kesehatan Kemenkes Tanjung Karang, Indonesia \\ $\bowtie$ Corresponding author e-mail: reniindriyani@poltekkes-tjk.ac.id, Alamat: Jalan Raya Hajimena Natar No.100 Kabupaten \\ Lampung Selatan, Indonesia 35362
}

\begin{abstract}
s
Background: Snack products that contain high calcium are rarely found in the community. It is necessary to change high calcium snacks to prevent and overcome nutritional problems, such as stunting. Purpose: Obtain the formula of spinach leaves (amaranthus hibrydus) and seaweed (eucheuma cottonii) on the calcium content of nori products. Methods: Experiment with Complete Randomized Block Design (RCBD) 3 times repetition. The formula used is a combination of spinach leaves and seaweed modified into 9 formulas, including 10:90, 20:80, 30:70, 40:60, 50:50, 60:40, 70:30, 80:20, and 10:90. The product is processed by drying. Making Nori with the modified drying method. Test of organoleptic nori products by 25 trained panelists. Results: The most preferred research results from the organoleptic test by panelists of Nori products were the Nori color rating scale in formula 9 (dark green), texture in formulation 8 (compact product texture) to formulation 9 (very compact texture). Panelist assessment on the scales of the formula obtained fluctuations occur and increased sharply in formula 9 (distinctive aroma of spinach), the most preferred flavor assessment in formula 5 and not preferred formula 1. Overall Panelist acceptance is most preferred on formula 9 (dark green, distinctive aroma spinach leaves and flavor are preferred in formula 9 (very compact texture), the highest calcium content test results obtained in formula 9 (90:10) with a calcium content of 1.89 mg. Conclusions: The best Nori products are produced from spinach leaves and seaweed formula (90:10) with organoleptic values of deep green color, typical of spinach leaves, very compact texture, preferred taste and overall acceptance preferred with the highest calcium content.
\end{abstract}

\begin{abstract}
Abstrak
Latar belakang : Produk camilan (snack) yang mengandung tinggi kalsium jarang ditemui di masyarakat. Perlu alterantif snack tinggi kalsium untuk mencegah atau mengatasi masalah gizi, seperti stunting dan osteoporosis. Tujuan: Memperoleh formula daun bayam (amaranthus hibrydus) dan rumput laut (eucheuma cottonii) terhadap kandungan kalsium produk nori. Metode: Eksperimen dengan Rancangan Acak Kelompok Lengkap (RAKL) 3 kali ulangan. Formula yang digunakan kombinasi daun bayam dan rumput laut yang dimodifikasi menjadi 9 formula, meliputi 10:90, 20:80, 30:70, 40:60, 50:50, 60:40, 70:30, 80:20, dan 10:90. Produk diolah dengan cara pengeringan. Pembuatan Nori dengan metode pengeringan yang dimodifikasi. Uji Produk nori Organoleptik oleh 25 Panelis terlatih. Hasil: Hasil penelitian dari penilaian uji Organoleptik oleh Panelis yang paling disukai dari produk Nori adalah skala penilaian warna nori pada formula 9 (warna hijau tua), tekstur pada formulasi 8 (tektur produk kompak) sampai formulasi 9 (tektur sangat kompak). Penilaian Panelis pada skala aroma diperoleh formula terjadi fluktuatif dan meningkat tajam pada formula 9 (aroma khas bayam), penilian rasa paling disukai pada formula 5 dan tidak disukai formula 1 . Penerimaan Panelis secara keseluruhan paling disukai pada formula 9 (warna hijau tua, aroma khas daun bayam dan rasa disukai pada formula 9 (tekture sangat kompak). Hasil uji kadar kalsium tertinggi diperoleh pada formula 9 (90:10) dengan kadar kalsium 1,83 mg. Simpulan: Produk nori yang terbaik dihasilkan dari formula daun bayam dan rumput laut (90:10) dengan nilai Organoleptik warna hijau tua, beraroma khas daun bayam, tektur sangat kompak, rasa disukai dan penerimaan keseluruhan disukai dengan kadar kalsium tertinggi.
\end{abstract}

Copyright (C) 2020 Jurnal Kesehatan Metro Sai Wawai. All rights reserved.

\author{
Kata kunci: \\ Produk nori; Formula daun \\ bayam; Rumput laut; \\ Kandungan kalsium; \\ Uji Organoleptik
}




\section{Latar Belakang}

Stunting dan osteoporosis masih menjadi masalah gizi yang belum tertangani dengan baik. Stunting merupakan salah satu bentuk kekurangan gizi yang ditandai dengan tinggi badan di bawah standard deviasi $(<-2 \mathrm{SD})$. Prevalensi stunting di Indonesia 30,2\%, angka ini masih berada di atas target WHO $(<$ $20 \%$ ). Prevalensi stunting seluruh propinsi di Indonesia yang berada di atas $20 \%$, kecuali DKI Jakarta, DI Yogyakarta, dan Bali, dan untuk provinsi Lampung 28,8\% (Balitbangkes RI, 2018). Osteoporesis merupakan penyakit yang timbul akibat penurunan masa tulang sehingga tulang mudah menjadi retak dan patah. Hal ini terjadi karena defesiensi kalsium dalam waktu yang lama, serta adanya penurunan hormon yang mempengaruhi proses mineralisasi tulang. Berdasarkan data pusat litbang gizi kementerian kesehatan penderita osteoporosis sebesar 19,7\% dan berada pada urutan keenam setelah cina (Ema, Purwanti \& Nurhidayat, 2015). Sasaran dari produk nori hasil penelitian ini diharapkan dapat menjadi bagian upaya untuk mengurangi atau mencegah, bahkan mengatasi permasalahan status gizi pada ibu hamil dan anak balita.

Konsumsi kalsium rata-rata masyarakat Indonesia termasuk rendah yaitu sebesar $254 \mathrm{mg} / \mathrm{hari}$ hanya seperemepat dari standard internasional (1000-1500 mg/hari) untuk orang dewasa (Kemenkes RI., 2019). Salah satu cara menanggulangi masalah stunting dan osteoporosis yaitu dengan meningkatkan asupan kalsium dalam produk makanan, pemberian suplementasi, peningkatan pengetahuan terkait makanan dan gizi orang tua atau pengasuh dan pemberian makanan tambahan (PMT) (Kemenkes RI., 2017).

Nori merupakan lembaran tipis yang terbuat dari rumput laut dan mulai digemari oleh masyarakat Indonesia. Nori dapat dimakan langsung sebagai camilan ataupun sebagai makanan pendamping sushi dan ramen. Nori biasanya terbuat dari rumput laut jenis pophyra, akan tetapi rumput laut tersebut sulit dibudidayakan di iklim tropis seperti Indonesia. Rumput laut yang banyak dibudidayakan di Indonesia adalah rumput laut jenis Eucheuma cottonii. Pada tahun 2010, FAO melaporkan bahwa Indonesia merupakan negara produsen terbesar untuk E. cottonii yaitu $63,37 \%$ dari total produksi dunia (Tim Perikanan WWF Indonesia, 2014). Masyarakat Indonesia menunjukan ketertarikan yang luar biasa pada camilan nori, hal ini dapat dilihat dari semakin banyak produk nori dalam kemasan yang di jual di pasarpasar swalayan (Agusta \& Hutami, 2017).

Balai Besar Pengembangan Budidaya Laut Lampung pada tahun 2013 melakukan uji multi lokasi terhadap rumput laut dibeberapa titik lokasi di Lampung yaitu di Pahawang, Ketapang, Sragi, dan Legundi dengan menyebar 7 ton bibit rumput laut, pada tempo 6 bulan telah berkembang lebih dari 1000 kali lipat bibit rumput laut, rumput laut $E$. cottonii memiliki aktivitas antioksidan sebesar 68,99\%, sedangkan daun bayam memiliki aktivitas antioksidan sebesar 22,10\% (Indriyani \& Subeki, 2017). Oleh karena itu, produk olahan rumput laut kurang enak, sehingga perlu dilakukan kombinasi dengan bahan lain. Rumput laut $E$. cottonii dapat dikombinasikan dengan daun bayam yang mengandung serat kasar 18,67\% (Yudhistira \& Affandi, 2019). Kombinasi yang pernah dilakukan dengan kolang kaling (Sari, Rahardjanto \& Husamah, Fauzi, 2019), sehingga diharapkan kombinasi rumput laut dan bayam dapat dibuat produk Nori.

Bayam adalah salah satu jenis sayuran daun yang banyak mengandung vitamin dan mineral (Rahayu, Asgar, Hidayat \& Djuariah, 2013). Daun Bayam (Amaranthus hibrydus) merupakan sayuran daun yang banyak mengandung gizi, antara lain protein, mineral, kalsium, zat besi, vitamin A dan C. Karena kandungan gizinya yang tinggi, maka bayam sering disebut sebagai raja sayuran atau king of vegetable (Purnawanto \& Suyadi, 2015). Bayam hijau memiliki manfaat baik bagi tubuh karena merupakan sumber kalsium, vitamin A, vitamin E dan vitamin C, serat, dan juga betakaroten. Selain itu, bayam juga memiliki kandungan zat besi yang tinggi untuk mencegah anemia (Agusta \& Hutami, 2017) serta kandungan mineral dalam bayam cukup tinggi (Shonte \& De Kock, 2017).

Kebiasaan makan snack dapat menyumbang $25 \%$ energi harian pada semua kelompok umur (Wang, Horst \& Eldridge, 2016). Produk camilan (snack) yang mengandung tinggi kalsium jarang ditemui di 
masyarakat. Oleh karena itu perlu adanya alterantif snack tinggi kalsium yang bermanfaat untuk kesehatan. Produk camilan (snack) adalah termasuk jenis makanan sekunder. Beberapa faktor seperti berbagai varian rasa, teksturnya yang renyah, harga yang variatif, kemasan yang menarik dan dapat disimpan dalam waktu yang relatif lama serta jenis juga bentuk yang beraneka ragam menjadikan produk camilan sangat diminati masyarakat sehingga peluang pasar bagi produk camilan menjadi sangat baik (Agusta \& Hutami, 2017)

Sumber makanan yang mengandung kalsium adalah susu, serealia, kacang-kacangan, tahu, tempe dan sayuran hijau. Sayuran hijau merupakan sumber kalsium yang sangat baik. Salah satu sayuran hijau yang mengandung kalsium yaitu sayuran bayam. Bayam merupakan sejenis tumbuhan yang biasa ditanam untuk dikonsumsi. Kandungan kalsium bayam bermanfaat untuk tubuh kita sehingga bayam sangat baik untuk dikonsumsi (Almatsier, 2015). Proses pengolahan daun bayam sangat terbatas dan tidak setiap manusia menyukainya, Oleh karena itu, perlu dilakukan upaya diversifikasi produk pangan menjadi nori untuk meningkatkan nilai tambah daun bayam, meningkatkan daya simpan produk daun bayam, dan untuk menarik peminat khususnya anak muda dan ibu-ibu hamil. Campuran rumput laut E. cottonii dan $U$. lactuca dapat diolah untuk menghasilkan produk nori yang berkualitas (Zakaria \& Priosoeryanto, 2017) dan dalam penelitian ini menggunakan rumput laut E. cottonii.

Daun bayam (Amaranthus hibrydus) merupakan salah satu jenis sayuran komersial yang mudah diperoleh di pasar tradisional maupun pasar swalayan. Umumnya tanaman bayam dikonsumsi pada bagian daun dan batangnya. Masyarakat yang sudah terbiasa mengkonsumsi daun bayam dapat merasakan kelezatan dan dapat meningkatkan selera makan. Bayam dapat digunakan sebagai bahan masakan untuk gado-gado, sayur bening, pecel dan dapat dibuat keripik bayam yang rasanya gurih dan renyah. Kandungan daun bayam dalam $100 \mathrm{~g}$ bahan adalah kalori (90 kal), air (77 g), protein (6,8 g), lemak (1,2 g), karbohidrat (13 g), kalsium (165 mg), fosfor (54 mg), besi (2 g), retinol (3300 ug), thiamin (0,12 ug), dan asam askorbat $(275 \mathrm{mg})$. Dilihat dari kandungan gizinya, bayam merupakan jenis sayuran hijau yang banyak manfaatnya untuk kesehatan. Terutama untuk anak-anak dan wanita hamil. Daun bayam dapat digunakan sebagai antikanker, mencegah konstipasi dan anemia, serta meningkatkan daya tahan tubuh. Kandungan vitamin dan mineralnya lebih tinggi dibandingkan dengan sayuran daun lainnya. Vitamin A dan $C$ daun bayam berperan sebagai antioksidan yang mencegah proses penuaan dan meningkatkan daya tahan tubuh terhadap penyakit. Kandungan kalsium yang tinggi sangat baik untuk mencegah penyakit tulang seperti rematik dan asam urat (Rahayu, Asgar, Hidayat \& Djuariah, 2013).

Kalsium merupakan mineral makro yang sangat dibutuhkan oleh tubuh manusia. Kalsium bermanfaat dalam pertumbuhan serta perkembangan tulang dan gigi agar mencapai ukuran dan kekuatan maksimal, mengatur pembukuan darah, katalisator reaksi-reaksi biologis dan kontraksi otot (Almatsier, 2015). Asupan kalsium yang optimal dan vitamin D yang memadai diperlukan untuk memaksimalkan pertumbuhan tulang. Meningkatkan asupan kalsium dan vitamin D selama kehamilan memiliki dampak positif terhadap perkembangan tulang janin pada kehamilan remaja. Pola makan yang baik akan cukup menyediakan zat gizi yang dibutuhkan untuk kesehatan kehamilan dan mengurangi resiko bayi lahir cacat. Selain itu, makan yang baik akan meningkatkan sistem pertahanan tubuh ibu hamil terhadap terjadinya infeksi (Mulya \& Bahar, 2014). Kekurangan kalsium pada ibu hamil dapat mempengaruhi pertumbuhan pada janinnya seperti pembentukan janin kurang sempurna, tulang dan giginya. Sedangkan, pada ibu hamil kekurangan kalsium bisa mengakibatkan osteoporosis dini, sakit gigi dan kram. Kekurangan asupan kalsium didapatkan pada sebagian besar kasus studi yang berhubungan dengan hipertensi dalam kehamilan. Kejadian hipertensi disebabkan antar lain zat gizi dalam makanan (Nofita \& Anjansari, 2018).

Penelitian ini mengkaji pengaruh formula proporsi kombinasi rumput laut (Amaranthus hibrydus) dan rumput laut (Eucheuma cottonii) terhadap kandungan kalsium dan orgonoleptik nori untuk memperoleh produk makanan Nori. Kombinasi daun bayam dan rumput laut dengan 9 formula yang masih jarang ditemukan atau diteliti. Selain itu, diperiksa konsentrasi kandungan kalsium mengandung berapa 
gram. Oleh karena itu, tujuan penelitian ini adalah untuk mengetahui efek formula proporsi daun bayam (Amaranthus hibrydus) dan rumput laut (Eucheuma cottonii) terhadap kandungan kalsium dan orgonoleptik Nori. Secara spesifik untuk mengetahui pengaruh proporsi daun bayam (Amaranthus hibrydus) dan rumput laut (Eucheuma cottonii) terhadap Organoleptik (warna, aroma, rasa, tekstur dan penerimaan keseluruhan) nori. mengetahui pengaruh proporsi daun bayam (Amaranthus hibrydus) dan rumput laut (Eucheuma cottonii) terhadap kadar kalsium nori dan mengetahui proporsi daun bayam (Amaranthus hibrydus) dan rumput laut (Eucheuma cottonii) yang paling disukai.

\section{Metode}

Penelitian ini menggunakan metode eksperimen untuk menghasilkan produk nori yang paling disukai, dengan metode Rancangan Acak Kelompok Lengkap (RAKL) dengan 3 kali ulangan, pengolahan dengan cara pengeringan, karena menurut penelitian sebelumnya bahwa nori yang pengeringan lebih disukai (Zakaria \& Priosoeryanto, 2017). Alat dan Bahan yang digunakan meliputi daun bayam, rumput laut, gula garam, saus teriyaki, timbangan makanan elektrik, blender, baskom plastik, sendok ukur, mabkok plastic, pisau satinless, saringan, Loyang kue, oven, cetakkan nori. Sedangkan, alat yang digunakan untuk analisis kadar kalsium adalah timbangan digital, pipet ukur, tabung reaksi, gelas ukur, erlenmayer, mikro pipet, mortal, buret, bulb dan arloji. Daun bayam (Amaranthus hibrydus) dan rumput laut (Eucheuma cottonii) didapat dari Pasar Smep Bandar Lampung. Kualitas bayam dan rumput laut dalam keadaan baik dan segar, sesuai dengan standart.

Prosedur pembuatan nori dari kombinasi daun bayam (Amaranthus hibrydus) dan rumput laut (Eucheuma cottonii) dilakukan dengan metode pengeringan (Ramadhan, Dhahiyat, \& Liviawaty, 2019) yang dimodifikasi. Langkah-langkahnya meliputi: (1) Daun bayam dan rumput laut dibersihkan dan dicuci dengan air mengalir, (2) Daun bayam dan rumput laut dikombinasikan dengan perbandingan 10:90 (P1), 20:80 (P2), 30:70 (P3), 40:60 (P4) 50:50 (P5), 60:40 (P6), 70:30 (P7), 80:20 (P8), dan 90;10 (P9), (3) Kombinasi daun bayam dan rumput laut total sebanyak $150 \mathrm{~g}$, kedua bahan tersebut dihancurkan dengan menggunkan blender hingga halus, kemudian ditambahkan gula dan garam masing-masing sebanyak $5 \%$, (4) Nori dicetak dan dikeringkan pada suhu kamar selama 3 hari, nori diangkat dari cetakan, kemudian direbus selama satu menit dengan ditambahkan saus teriyaki, gula dan garam sebanyak $10 \%$ dan (5) Lembaran nori telah direbus dikeringkan selama 2 jam pada suhu kamar dan kemudian dioven pada suhu $60^{\circ} \mathrm{C}$ selama 5 menit.

Langkah selanjutnya dilakukan uji Organoleptik dilakukan dengan menggunakan atau mengandalkan panca indera manusia sebagai alat pengukur daya terima terhadap suatu produk makanan. Pengukuran dilakukan untuk mengidentifikasi warna, rasa aroma dan teksture, oleh 25 orang mahasiswa panelis yang sudah terlatih menggunakan metode mutu hedonik, dengan menggunakan skor 5-1. Parameter warna dengan kriteria hijau tua skor (5), hijau (4), Coklat kehijauan (3), coklat (2) dan coklat tua (1). Parameter Aroma dengan kriteria Sangat beraroma khas daun bayam (5), beraroma daun bayam (4), Agak beraroma daun bayam (3), tidak beraroma daun bayam (2) dan sangat tidak beraroma daun bayam (1). Parameter Rasa dengan kriteria amat sangat disukai (5) snagat disukai (4), disukai (3), Agak kurang disukai (2) dan kurang disukai (1). Parmeter Tekture dengan kriteria Sangat kompak (5), kompak (4), agak kompak (3), tidak kompak (3) sangat tidak kompak (1). Parameter Penerimaan keseluruhan denga kriteria sangat disukai (5), Sangat disukai (4), disukai (3), agak kurang disukai (2), kurang disukai (1).

Nori yang telah diberikan penilaian Panelis, selanjutnya data Organoleptik dilakukan analisis univariat dengan menggunakan tampilan berupa tabel dan grafik dan analisis bivariat menggunakan uji 
analisis of variant (Anova) dengan tingkat kesalahan $(\alpha) 5 \%$ atau 0,05. Sedangkan, uji kadar kalsium produk nori yang dihasilkan dengan menggunakan metode volumetric.

\section{Hasil}

\section{Uji Organoleptik}

Penilaian Organoleptik ditujukan kepada pengaruh formula penambahan bayam dengan rumput laut dengan perbandingan 10:90 (P1), 20:80 (P2), 30:70 (P3), 40:60 (P4), 50:50 (P5), 60:40 (P6), 70:30 (P7), 80:20 (P8), 90:10 (P9). Hasil Uji Organoleptik terhadap warna produk nori dengan perbandingan antara daun bayam (Amaranthus hibrydus) dan rumput laut (Eucheuma cottonii) dapat dilihat pada tabel 1.

Tabel 1 memperlihatkan bahwa nilai rata-rata skala penilaian Panelis tentang warna produk meningkat berbanding lurus dengan banyaknya proporsi bayam dalam formula, formula 9 adalah formula yang memiliki warna yang paling disukai oleh panelis dengan komposisi 90:10 (daun bayam:rumput laut). Hasil analis memperlihatkan ada perbedaan yang signifikan minimal satu formula bayam dan rumput laut $(\mathrm{p}=0,000)$. Sedangkan, pada nilai rata-rata tekstrur memberikan informasi adanya fluktuasi skala penilaian tekstur oleh Panelis, tetapi terjadi peningkatan pada formulasi 8 hingga formula 9. Hasil uji statistis menunjukkan ada perbedaan yang nyata rata-rata skala penilaian tekstur diantara ke- 9 formula $(\mathrm{p}=0,000)$. Selanjutnya informsi skala aroma panelis terjadi fluktuatif dan meningkat tajam pada formula 9. Hasil uji statistik ada pengaruh rata-rata penilaian skala aroma dan rata-rata penilaian tekstur formula 9 merupakan formula yang memiliki nilai rata-rata aroma paling tinggi $(\mathrm{p}=0,005)$.

Informsi rerata penilaian skala rasa pada masing-masing panelis pada formula, fluktuatif dan puncaknya pada formula 5 (50:50). Hasil uji statistik menunjukkan ada perbedaan rata-rata penilaian skala rasa dan bila dilihat dari rata-rata penilaian aroma, formula 5 merupakan formula yang memiliki nilai ratarata rasa paling tinggi. Informsi rerata penilaian skala keseluruhan oleh Panelis meningkat sebanding dengan formula yang telah diberikan. Hasil uji statistik menunjukkan bahwa ada perbedaan rata-rata penilaian skala keseluruhan dan bila dilihat dari rata-rata penilaian keseluruhan, formula 9 merupakan formula yang memiliki nilai rata-rata rasa paling tinggi.

Pengujian kadar kalsium adanya peningkatan kadar kalsium pada formula produk ini semakin tinggi sebanding lurus dengan peningkatan proporsi daun bayam. Hasil statistik pengujian kadar kalsium membuktikan ada perbedaan paling sedikit satu kadar kalsium pada 9 komposisi formula produk nori ( $p$ value 0,000). Hasil uji statistik homogeneous tukey memperoleh nilai rata-rata kadar tertinggi pada formula 9 dengan kadar kalsium 1,83 gr

Grafik 1 menunjukkan hasil penilaian organoleptic mempunyai kecenderungan meningkat dengan terdapat 2 penilaian yang fluktuatif yaitu pada nilai aroma dan rasa. Komposisi yang paling disukai panelis umumnya adalah formula 9 kecuali pada penilaian rasa, formula 5 adalah formula yang paling disukai.

\section{Pembahasan}

\section{Nori yang paling disukai}

Penerimaan keseluruhan merupakan komposit dari nilai tiap pertanyaan, untuk penilaian keseluruhan tentang warna, tekstur, aroma, dan rasa, dengan kriteria amat sangat disukai, sangat disukai disukai, agak kurang disukai dan kurang disuka. Pada penerimaan keseluruhan didapatkan formula yang paling disukai adalah formula 9 dengan komposisi 90:10 (bayam : Rumput laut). Hasil uji Organoleptik diperoleh penilaian oleh Panelis meliputi penilaian warna nori, tekstur nori, aroma nori dan rasa nori.

\section{Warna nori}

Warna merupakn variabel yang mempengaruhi penampilan dan mutu suatu produk. Warna merupakan indikator konsumen untuk tertarik atau perhatian dan paling cepat memberikan kesan bahwa 
Efek Formula Daun Bayam dan Rumput Laut Meningkatkan Kandungan Kalsium dalam Produk Nori yang Disukai Reni Indriyani, Dewi Sri Sumardilah

Jurnal Kesehatan Metro Sai Wawai. Vol 13, No 1, Juni 2020

Tabel 1.

Penilaian Organoleptik nori terhadap formula daun bayam (amaranthus hibrydus) dan rumput laut

\begin{tabular}{|c|c|c|c|c|}
\hline $\begin{array}{c}\text { Formulasi } \\
\text { Bayam : Rumput Laut }\end{array}$ & Mean & Standar Deviasi & $95 \%$ CI & P-value \\
\hline \multicolumn{5}{|l|}{ Warna Nori } \\
\hline Formula $1(10: 90)$ & 4,02 & 0,21 & $3,93-4,11$ & 0,000 \\
\hline Formula $2(20: 80)$ & 3,82 & 0,46 & $3,63-4,01$ & \\
\hline Formula $3(30: 70)$ & 3,93 & 0,50 & $3,72-4,41$ & \\
\hline Formula $4(40: 60)$ & 4,10 & 0,44 & $3,92-4,29$ & \\
\hline Formula $5(50: 50)$ & 4,15 & 0,43 & $3,87-4,39$ & \\
\hline Formula $6(60: 40)$ & 4,13 & 0,63 & $4,17-4,35$ & \\
\hline Formula 7 (70:30) & 4,26 & 0,21 & $4,25-4,62$ & \\
\hline Formula $8(80: 20)$ & 4,43 & 0,44 & $4,49-4,73$ & \\
\hline Formula $9(90: 10)$ & 4,61 & 0,30 & $4,10-4,23$ & \\
\hline \multicolumn{5}{|l|}{ Tekstur Nori } \\
\hline Formula $1(10: 90)$ & 3,73 & 0,59 & $3,48-3,97$ & 0,000 \\
\hline Formula $2(20: 80)$ & 3,66 & 0,63 & $3,40-3,92$ & \\
\hline Formula $3(30: 70)$ & 3,69 & 0,66 & $3,41-3,96$ & \\
\hline Formula $4(40: 60)$ & 3,52 & 0,48 & $3,32-3,71$ & \\
\hline Formula $5(50: 50)$ & 3,70 & 0,64 & $3,44-3,97$ & \\
\hline Formula $6(60: 40)$ & 3,82 & 0,68 & $3,54-4,10$ & \\
\hline Formula 7 (70:30) & 3,42 & 0,39 & $4,05-4,37$ & \\
\hline Formula $8(80: 20)$ & 4,26 & 0,27 & $4,10-4,43$ & \\
\hline Formula $9(90: 10)$ & 4,45 & 0,62 & $4,43-4,56$ & \\
\hline \multicolumn{5}{|l|}{ Aroma Nori } \\
\hline Formula $1(10: 90)$ & 3,73 & 0,59 & $3,48-3,97$ & 0,000 \\
\hline Formula $2(20: 80)$ & 3,66 & 0,63 & $3,40-3,92$ & \\
\hline Formula 3 (30:70) & 3,69 & 0,66 & $3,41-3,96$ & \\
\hline Formula 4 (40:60) & 3,52 & 0,48 & $3,32-3,71$ & \\
\hline Formula $5(50: 50)$ & 3,70 & 0,64 & $3,44-3,97$ & \\
\hline Formula $6(60: 40)$ & 3,82 & 0,68 & $3,54-4,10$ & \\
\hline Formula $7(70: 30)$ & 3,42 & 0,39 & $4,05-4,37$ & \\
\hline Formula $8(80: 20)$ & 4,26 & 0,27 & $4,10-4,43$ & \\
\hline Formula $9(90: 10)$ & 4,45 & 0,62 & $4,43-4,56$ & \\
\hline \multicolumn{5}{|l|}{ Rasa Nori } \\
\hline Formula $1(10: 90)$ & 2,93 & 0,57 & $2,69-3,17$ & 0,000 \\
\hline Formula $2(20: 80)$ & 2,98 & 0,66 & $2,71-3,26$ & \\
\hline Formula 3 (30:70) & 3,45 & 0,38 & $3,29-3,61$ & \\
\hline Formula 4 (40:60) & 3,54 & 0,67 & $3,26-3,82$ & \\
\hline Formula $5(50: 50)$ & 3,88 & 0,81 & $3,54-4,21$ & \\
\hline Formula $6(60: 40)$ & 3,40 & 0,59 & $3,15-3,64$ & \\
\hline Formula $7(70: 30)$ & 3,26 & 0,64 & $2,99-3,53$ & \\
\hline Formula $8(80: 20)$ & 3,12 & 0,65 & $2,94-3,48$ & \\
\hline Formula $9(90: 10)$ & 3,34 & 0,53 & $3,19-3,63$ & \\
\hline \multicolumn{5}{|l|}{ Nori yang disukai } \\
\hline Formula $1(10: 90)$ & 3,38 & 0,18 & $3,30-3,46$ & 0,000 \\
\hline Formula $2(20: 80)$ & 3,41 & 0,33 & $3,27-3,55$ & \\
\hline Formula 3 (30:70) & 3,63 & 0,35 & $3,48-3,77$ & \\
\hline Formula 4 (40:60) & 3,59 & 0,29 & $3,46-4,71$ & \\
\hline Formula $5(50: 50)$ & 3,80 & 0,36 & $3,65-3,95$ & \\
\hline Formula $6(60: 40)$ & 3,71 & 0,40 & $3,55-3,88$ & \\
\hline Formula 7 (70:30) & 3,94 & 0,27 & $3,83-4,05$ & \\
\hline Formula 8 (80:20) & 4,03 & 0,25 & $3,93-4,14$ & \\
\hline Formula $9(90: 10)$ & 4,17 & 0,26 & $4,07-4,28$ & \\
\hline \multicolumn{5}{|l|}{ Uji Kadar Kalsium } \\
\hline Formula $1(10-90)$ & 0,27 & 0,044 & $0,16-0,38$ & 0,000 \\
\hline Formula $2(20-80)$ & 0,44 & 0,044 & $0,33-0,55$ & \\
\hline Formula $3(30: 70)$ & 0,62 & 0,044 & $0,51-0,73$ & \\
\hline Formula $4(40: 60)$ & 0,81 & 0,067 & $0,65-0,98$ & \\
\hline Formula $5(50: 50)$ & 0,99 & 0,067 & $0,82-1,16$ & \\
\hline Formula $6(60: 40)$ & 1,17 & 0,06 & $1,00-1,34$ & \\
\hline Formula $7(70: 30)$ & 1,36 & 0,09 & $1,13-1,59$ & \\
\hline Formula $8(80: 20)$ & 1,54 & 0,05 & $1,41-1,67$ & \\
\hline Formula $9(90: 10)$ & 1,84 & 0,06 & $1,67-2,00$ & \\
\hline
\end{tabular}




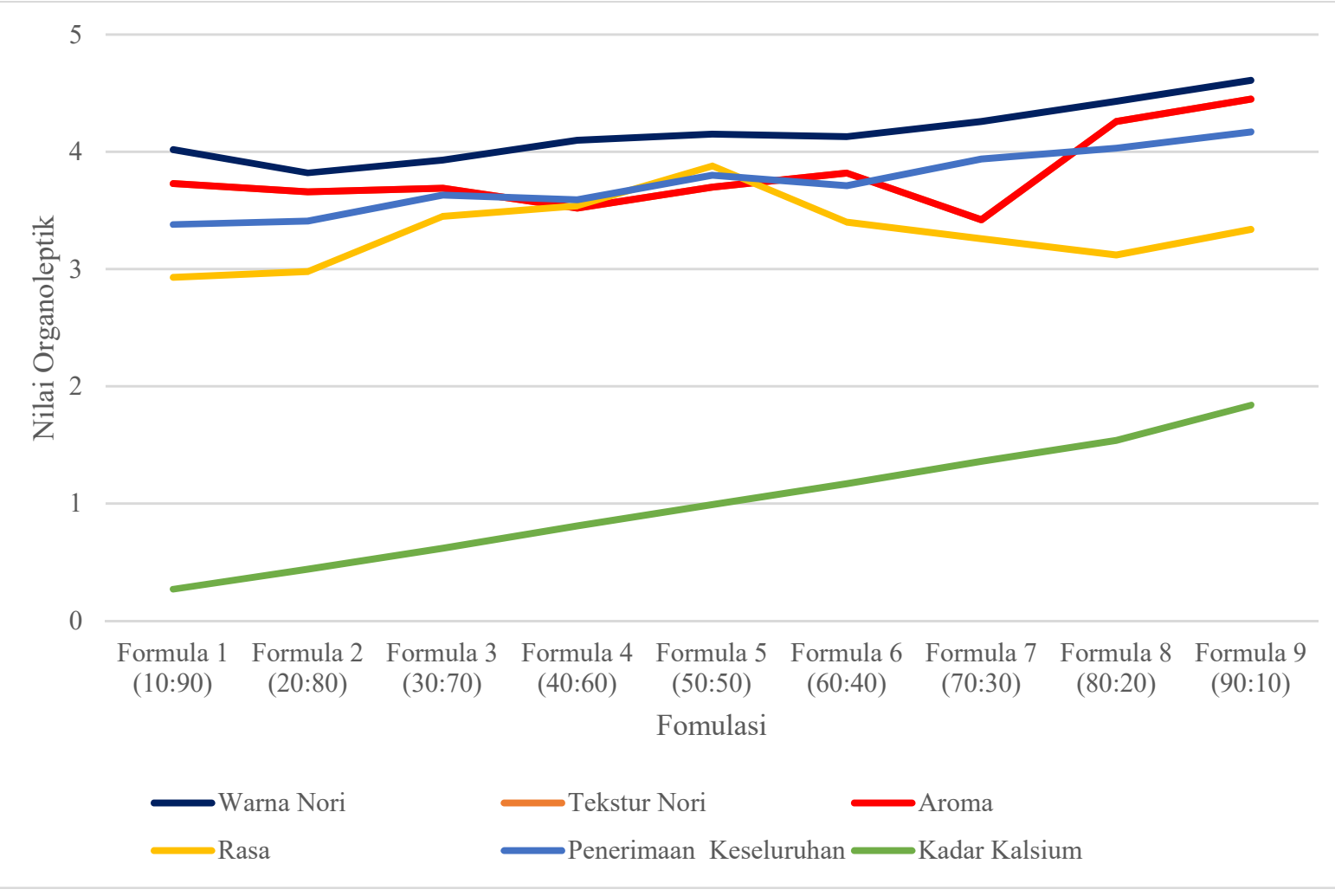

\section{Grafik 1.}

Penilaian Organoleptic Nori terhadap Formula Daun Bayam

produk tersebut disukai (Agusta \& Hutami, 2017). Pada uji organoleptic untuk pembedaan rangking sederhana untuk melihat mutu warna, panelis diminta untuk menilai warna lebih cerah dengan mengurutkan rangking 1 dari yang warnanya paling cerah hingga rangking 3 yang dianggap memiliki warna yang paling tidak cerah, yaitu hijau tua, hijau, coklat kehijauan, coklat, dan coklat tua. Kualitas suatu produk pangan ditentukan oleh penampilan fisik salah satunya warna, dengan penampilan yang baik akan mempengaruhi penerimaan konsumen terhadap suatu produk (Rahayu, Asgar, Hidayat \& Djuariah, 2013).

Formula dalam penelitian ini melalui uji organoleptic didapatkan formula yang paling disukai adalah formula 9 (komposisi 90 bayam dan 10 rumput laut) dan komposisi yang paling tidak disukai pada formula 2 (komposisi 20 bayam dan 80 rumput laut). Formula 9 dengan komposisi bayam lebih banyak dari rumput laut lebih disukai panelis karena jenis bayam yang digunakan adalah bayam yang ditanam secara lokal lebih disukai karena kualitas Organoleptik cukup tinggi (Batziakas, Talavera, Stueve, Rivard, \& Pliakoni, 2019).

Hasil pengamatan di pasaran, jenis camilan nori yang beredar di masyarakat cenderung memiliki memiliki warna hijau yang relative lebih cerah dibandingkan dengan nori yang digunakan sebagai bahan penyalut (Agusta \& Hutami, 2017). Parameter fisik merupakan salah satu hal yang mempengaruhi penerimaan konsumen terhadap produk. Konsumen tentu akan memilih nori yang berpenampilan menarik seperti warna yang cerah (Rahayu, Asgar, Hidayat \& Djuariah, 2013). Produk nori formula 9 menghasilkan warna hijau yang dapat direkomendasikan untuk digunakan di masyarakat.

\section{Tekstur nori}

Uji pembedaan rangking sederhana terhadap atribut mutu tekstur, panelis diminta untuk mengurutkan tingkat kekompakan masing-masing sampel dari ke-9 komposisi perlakuan dari yang 
dianggap paling Sangat kompak, kompak, agak kompak, tidak kompak, dan sangat tidak kompak. Tekstur merupakan sensasi tekanan yang dapat diamati dengan mulut atau perabaan dengan jari, dan konsistensi merupakan tebal, tipis dan halus; Indra pembau, pembauan juga dapat digunakan sebagai suatu indikator terjadinya kerusakan pada produk (Wahyuningtias, 2010). Semakin besar nilai tekstur menunjukkan tekstur semakin lunak (Rahayu, Asgar, Hidayat \& Djuariah, 2013) Pada penelitian ini menunjukkan tekstur terbaik pada formula 9 dan tekstur terburuk pada formula 5, dengan demikian produk nori formula 9 dapat dipasarkan. Karakteristik morfologi bayam secara umum, memiliki tekstur benuk daun bayam yang lunak dengan rasa netral (Shonte \& De Kock, 2017).

\section{Aroma nori}

Aroma didefinisikan sebagai sesuatu yang bisa diamati dengan indra pembau dan dianggap penting karena bisa menghasilkan penelitian terhadap penerimaan atau penolakan terhadap produk dengan cepat (Agusta \& Hutami, 2017). Penilaian aroma berupa sangat beraroma khas daun bayam, beraroma khas daun bayam, masih beraroma daun bayam, tidak beraorama daun bayam dan sangat tidak beraroma daun bayam. Pada hasil formula dinilai pada aroma didapatkan formula yang paling disukai adalah formula 9 dan tidak disukai formula 1.

\section{Rasa nori}

Rasa yang diujikan dalam uji rangking perbedaan sederhana ini dilakukan untuk mengetahui urutan sampel yang dianggap amat sangat disukai, sangat disukai, disukai, agak kurang disukai, dan kurang disukai. Berdasarkan hasil penelitian, panelis lebih menyukai rasa pada formula 5 dengan komposisi bayam dan rumput laut (50:50). Rasa pada nori berasal dari asam amino alanin, asam glutamate dan glisin yang terdapat dalam rumput laut. Asam amino lainnya yaitu arginin merupakan asam amino yang biasanya terdapat dalam protein hewani. Selain beberapa asam amino yang dapat ditemukan dalam rumput laut, terdapat juga taurin yang diketahui efektif untuk fungsi hati, mencegah terjadinya penyakit batu empedu serta mengontrol kolesterol darah (Loupatty, 2014).

\section{Kadar kalsium pada produk nori formula daun bayam dan rumput laut}

Hasil uji kadar kalsium pada formula 9 (90:10) dengan kadar kalsium 1,83 mg. Berdasarkan penelitan dari Lalopua tahun 2017 kandungan kalsium pada nori dari bahan baku alga hypnea saidana dan Ulva conglubata sebesar 755,21 ppm (Lalopua, 2017). Penelitian ini jika dibandingan dengan penelitian Lalopua (2017) memperlihatkan terdapat keunggulan kandungan kalsium lebih tinggi. Penggunaan bahan bayam dalam penelitian ini dapat meningkatkan kandungan kalsium. Bayam hijau memiliki manfaat baik bagi tubuh karena merupakan sumber kalsium. Kandungan kalsium dalam bayam dapat mencegah pengapuran tulang (Zakaria \& Priosoeryanto, 2017). Pada usia muda kebutuhan kalsium tidak tercukupi, sehingga pada usia lanjut akan lebih berisiko osteoporosis dan mengalami fraktur (Setyawati \& Salimar, 2018). Daun bayam jenis Amarhantus hybridus memiliki kandungan kalsium yang tinggi (Shonte \& De Kock, 2017). Rumput laut juga berkontribusi pada sumber kalsium hingga mencapai $7 \%$ dari berat kering dan $25-34 \%$ dari rumput laut yang mengandung kapur. Konsumsi rumput laut sangat berguna bagi ibu yang sedang hamil, para remaja, dan orang lanjut usia yang kemungkinan dapat terkena risiko kekurangan (defisiensi) kalsium (Suparmi \& Sahri, 2009).

\section{Simpulan}

Formula daun bayam (Amaranthus hibrydus) dan rumput laut (Eucheuma cottonii) dengan kadar kalsium tertinggi nori pada formula 90:10 dengan nilai 1,83 mg. Sedangkan, formula daun bayam 
(Amaranthus hibrydus) dan rumput laut (Eucheuma cottonii) yang paling disukai dan terbaik pada Formula 90 : 10 (daun bayam : rumput laut), yaitu pada warna hijau, tekture kompak dan beraroma daun bayam. Untuk memperoleh produk nori lain, masih perlu dikembangkan penambahan cita rasa untuk meningkatkan kesukaan produk pada konsumen dan perlu adanya penelitian lebih lanjut pembuatan nori dengan formula rumput laut dengan selain dari daun bayam.

\section{Ucapan terima kasih}

Terimakasih kami sampaikan kepada Pusat Penelitian dan Pengabdian masyarakat Poltekkes Kemenkes Tanjung Karang yang telah membiayai penelitian hingga selesai, Jurusan Gizi Poltekkes Tanjung Karang yang digunakan sebagai tempat pembuatan produk nori, dan Laboratorium uji mutu hasil pertanian Universitas Lampung sebagai tempat untuk analisis kadar kalsium.

\section{Referensi}

Almatsier, S. (2015). Prinsip ilmu gizi dasar (ke-8). Jakarta: PT Gramedia Pustaka Utama.

Balitbangkes RI. (2018). Laporan nasional Riset Kesehatan dasar (Riskesdas) tahun 2018. Jakarta: Balitbangkes RI.

Yudhistira, T. R. S. B, \& Affandi, D. R. (2019). Karakteristik fisik, kimia dan organoleptik cookies bayam hijau (amaranthus tricolor) dengan penambahan tomat (solanum lycopersicum) sebagai upaya pemenuhan defisiensi zat besi pada anak-anak. Journal of Agro-based Industry, 36(2), 83-95. DOI: http://dx.doi.org/10.32765/warta\%20ihp.v36i2.5286

Batziakas, K. G., Talavera, M., Swaney-Stueve, M., Rivard, C. L., \& Pliakoni, E. D. (2019). Descriptive analysis and consumer acceptability of locally and commercially grown spinach. Journal of Food Science, 84(8), 22612268. DOI: https://doi.org/10.1111/1750-3841.14710

Wang, D., Klazine van der Horst, E. J., \& Eldridge, A. L. (2016). Snacking among US children : patterns differ by time of day distribution of snacking. Journal of Nutrition Education and Behavior, 48(6), 369-375.e1. DOI: https://doi.org/10.1016/j.jneb.2016.03.011

Agusta, E. N., \& Hutami, R. (2017). Fomulasi nori artifisial berbahan baku bayam (Amaranthus hybridus L.). Jurnal Agroindustri Halal, 3(April), 19-27. DOI: https://doi.org/http://dx.doi.org/10.30997/jah.v3i1.685

Indriyani, R., \& Subeki. (2017). Kajian pembuatan nori dari kombinasi daun singkong (manihot esculenta) dan rumput laut (eucheuma cottonii). Prosiding Unila, 3(1), 68.

Kemenkes RI. (2019). Profil Kesehatan Indonesia 2018 (pertama). Jakarta: Kemenkes RI.

Kemenkes RI. (2017). Profil Kesehatan Indonesia Tahun 2016. Jakarta: Kemenkes RI.

Lalopua, V. M. N. (2017). Pemanfaatan dan karakteristik nori tiruan menggunakan bahan baku alga hypnea saidana dan ulva conglubata dari perairan Maluku. Majalah BIAM, 13(2), 33-40. DOI: http://dx.doi.org/10.29360/mb.v13i2.3529

Ema, L., Purwanti, E. P., \& Nurhidayat, S. (2015). The risk factors osteopenia on adolescent. Jurnal Ners dan Kebidanan (Journal of Ners and Midwifery), 2(1), 038-042. DOI: https://doi.org/10.26699/jnk.v2i1.art.p038042

Loupatty, V. D. (2014). Nori nutrient analysis from seawed of porphyra marcossi in Maluku Ocean. Eksakta, 14(2), 34-48. DOI: https://doi.org/10.20885/eksakta.vol14.iss2.art4

Mulya, F. M., \& Bahar, H. (2014). Hubungan asupan suplemen kalsium pada ibu hamil dengan panjang bayi saat lahir di wilayah cengkareng. Nutrire Diaita, 6(2), 81-98. https://ejurnal.esaunggul.ac.id/index.php/Nutrire/article/view/1266/1158

Nofita, R., \& Anjansari, F. R. (2018). Korelasi waktu pemberian kalsium, dan kepatuhan konsumsi kalsium dengan kejadian resiko tinggi pre eklamsia ibu hamil di wilayah kerja puskesmas ciputat. Indonesian Journal of Midwivery (IJM), 1(1), 41-48. DOI: http://dx.doi.org/10.35473/ijm.v1i1.39

Purnawanto, A. M., \& Suyadi, A. (2015). Keragaan organ source dua varietas bayam cabut pada variasi media tanam arang sekam. AGRITECH, XVII(1), 87-96. DOI: 10.30595/agritech.v17i1.1348 
Sari, D. K , Rahardjanto, A., \& Husamah, Fauzi, E. P. T. P. A. (2019). The formulation of artificial nori with the base mixture ingredients of gracilaria sp. And arenga pinnata (wurmb) merr. Using the natural colorant from pleomele angustifolia (Medik) N.E. Br. International Conference on Life Sciences and Technology, 1-11. DOI: https://doi.org/10.1088/1755-1315/276/1/012013

Setyawati, B., Fuada, N., \& Salimar. (2018). Pengetahuan tentang osteoporosis dan kepadatan tulang hubungannya dengan konsumsi kalsium pada wanita dewasa muda. Maternal, 1(1), 1-10. DOI: https://doi.org/10.20473/amnt.v1.i2.2017.88-97

Shonte, T. T., \& de Kock, H. L. (2017). Descriptive sensory evaluation of cooked stinging nettle (Urtica dioica L.) leaves and leaf infusions: Effect of using fresh or oven-dried leaves. South African Journal of Botany, 110, 167-176. DOI: https://doi.org/10.1016/j.sajb.2016.11.010

Suparmi, \& Sahri, A. (2020). Mengenal potensi rumput laut : kajian pemanfaatan sumber daya rumput laut dari aspek industri dan kesehatan. Sultan agung, XLIV(118), 95-116. http://jurnal.unissula.ac.id/index.php/majalahilmiahsultanagung/article/view/252

Rahayu, S. T., Asgar, A., Hidayat, I.M.K., \& Djuariah, D. (2013). Evaluasi kualitas beberapa genotipe bayam ( amaranthus sp ) pada penanaman di jawa barat [ Quality Evaluation of Some Genotype of Spinach ( Amaranthus sp .) Cultivated in West Java ]. Berita Biologi, 12(2), 153-160. DOI: https://doi.org/10.14203/beritabiologi.v12i2.527

Ramadhan, Y. A., Afriyanto, E.., Dhahiyat, Y., \& Liviawaty, E. (2019). Differences of the way of drying nori from raw seaweed Gracilaria sp . based on the level of preference. Scientific News of Pacific Region, 4(June), 111. http://psjd.icm.edu.pl/psjd/element/bwmeta1.element.psjd-5bc77047-a8a9-4e3e-9e23-ce1 fceaf4bcd

Zakaria, F. R., \& Priosoeryanto, B. P. (2017). Karakteristik nori dari campuran rumput laut Ulva lactuca dan Eucheuma cottonii. JPB Kelautan dan Perikanan, 12(1), 23-30. DOI: http://dx.doi.org/10.15578/jpbkp.v12i1.336

Wahyuningtias, D. (2010). Uji organoleptik hasil jadi kue menggunakan bahan non instant dan instant. Binus Business Review, 1(9), 116-125. DOI: https://doi.org/10.21512/bbr.v1i1.1060

Sitasi: $\quad$ Indriyani, R \& Sumardilah, D. S. (2020). Efek Formula Daun Bayam dan Rumput Laut Meningkatkan Kandungan Kalsium dalam Produk Nori yang Disukai. Jurnal Kesehatan Metro Sai Wawai. 13(1). 1-10. DOI: 10.26630/jkm.v13i1.1925

Hiperlink DOI: $\quad$ http://dx.doi.org/10.26630/jkm.v13i1.1925 